\section{INDOKOLT AZ OPTIMIZMUS A DÍJTÁMOGATOTT \\ NÖVÉNYBIZTOSÍTÁSOK KAPCSÁN \\ 2016-BAN TÖBB MINT 2 MILLIÁRD FORINTTAL NÖTT A DÍJTÁMOGATOTT NÖVÉNYBIZTOSITTÁSOK ÁLLOMÁNYA}

Gazdag Gyula (Földmüvelésügyi Minisztérium, agrárbiztositási referens), Tanczné Óvári Csilla (Földmüvelésügyi Minisztérium, támogatáspolitikai elemzö)

\section{ÖSSZEFOGLALÓ}

Hazánkban öt éve részesülhetnek mezőgazdasági biztosítási dijtámogatásban a termelők. Ezalatt a rendszer jogszabályi alapja többször változott: 2014-ig az Európai Mezőgazdasági Garancia Alap szabályai alapján finanszírozott programként múködött, 2015-ben átmenetileg nemzeti támogatásként, 2016-tól pedig a Vidékfejlesztési Program keretében igényelhető a támogatás. Szerencsére a termelők a változásokból csak keveset érzékelhettek, hiszen a fỏbb biztosítási konstrukciók alig módosultak, és a díjtámogatott biztosítások egyre népszerűbbé válnak. Jelen összeállításunkban az elmúlt évek eredményeit és a közeljövőben várható változásokat kívánjuk bemutatni.

\section{SUMMARY}

In 2012 a new two-pillar risk management scheme has been introduced in the agricultural sector. Its second pillar is the premium support to crop and plant insurances. Present article is summarizing the past 5 years of agricultural insurance products supported by the government.

Kulcsszavak: mezőgazdasági biztosítás Keywords: agricultural insurance

JEL: G22, Q10

DOI: 10.18530/BK.2017.2.70

http://dx.doi.org/1018530/BK.2017.2.70
A biztosítási dijtámogatás 2012-es bevezetése óta a fejlődés töretlen, hiszen évről évre folyamatosan nő a díjtámogatott biztosítást kötő termelők és az igénybe vett módozatok száma, valamint a biztosítások dijállománya (1. táblázat). Az elmúlt évben különösen kiemelkedő volt a díjállomány növekedése (35\%), ami a 2015-ös szinthez képest több mint 2 milliárd forintos bővülést jelentett. Az ötéves fejlődést az alábbi adatok szemléltetik:

1. táblázat: Díjtámogatott termékek darabszáma és díjállománya 2012-2016

\begin{tabular}{|l|c|r|}
\hline $\mathbf{E} \mathbf{v}$ & Módozat (db) & Dijállomány (millió Ft) \\
\hline 2012 & 1896 & 1467 \\
\hline 2013 & 7741 & 4018 \\
\hline 2014 & 13088 & 5679 \\
\hline 2015 & 16318 & 5752 \\
\hline 2016 & 20694 & 7784 \\
\hline
\end{tabular}

Forrás: MABISZ, MVH

Az évről évre tapasztalható díjállomány-növekedés a rendszerben részt vevők közös munkájának sikerét jelzi, melynek eredményeként egyre többen foglalkoznak díjtámogatott biztosításokkal. Míg 2012-ben mindössze 3 piaci biztosító kínált díjtámogatott mezőgazdasági biztosításokat, addig 2016-ban már 4 piaci biztosító és 7 nonprofit biztosítóegyesület vett részt az értékesítésben. A csatlakozási lehetőség továbbra is nyitott a többi biztosító, nonprofit biztosítóegyesület számára, hiszen mindannyiunk közös célja, hogy a termelök minél szélesebb köréhez eljussanak a díjtámogatott biztosítások

Melyek a díjtámogatásban részesíthető biztosítási konstrukciók?

A rendszer indulása óta három növénybiztosítási konstrukció részesülhet támogatásban, melyeknek a lényeges elemei a következők:

$\mathrm{Az}$ „A” típusú biztosítás egyfajta csomagbiztosítás, ami azt jelenti, hogy valamennyi veszélynemre együttesen köthető. A konstrukció kockázatvállalása a jégesőkár, az aszálykár, a mezőgazdasági árvízkár, a téli fagykár, a tavaszi fagykár, az őszi fagykár, a felhőszakadáskár, a viharkár és a tüzkár térítésére terjed ki, a biztosítható növények pedig a legnagyobb vetésterületen termesztett szántóföldi növények, mint a búza, a kukorica, az őszi káposztarepce, a triticale, a rozs, az árpa és a napraforgó, valamint a hazánkban leggyakoribb ültetvények (szőlő, alma és körte).

A „B” típusú biztosítás keretében a jégesőkár, a téli fagykár, a viharkár és a tűzkár biztosítható, mely kockázatok külön-külön is választhatók. Ezzel a termékkel az „A” csomagban nem szereplő ültetvények, illetve a fontosabb zöldségnövények biztosíthatók.

A „C” típusú biztosítás kockázati köre megegyezik az „A” termékével, azzal a különbséggel, hogy a termelő megválaszthatja, hogy azok közül mely kockázatokra kíván biztosítást kötni. A „C” típusú biztosítás a kockázatkezelési szempontból releváns 
bármely növénykultúrára megköthető, melynek pontos listáját az Egységes Kérelem (EK) benyúitásához a kifizető ügynökség honlapján közzétett Hasznosítási Kódok tartalmazzák.

Az egyes díjtámogatott biztosítási konstrukciók (módozatok) igénybevétele nem egyforma, megoszlásukat 2016-ban a 2. táblázat mutatja.

2. táblázat: Az egyes dijitámogatott konstrukciók igénybevétele

\begin{tabular}{|l|c|c|}
\hline Módozat & Darabszám (db) & Díjállomány (millió Ft) \\
\hline „A" típus & 2920 & 3000 \\
\hline „B" típus & 11186 & 3442 \\
\hline "C” típus & 6588 & 1342 \\
\hline Összesen & 20694 & 7784 \\
\hline
\end{tabular}

Forrás: MABISZ, $M V H$

Az egyes biztosítási típusok eltérő elterjedtségének oka egyrészt a termelői biztosítási szokásokban, másrészt az egyes konstrukciókra vonatkozó eltérő támogatási intenzitásban keresendő. Amennyiben elegendő forrás áll rendelkezésre, a megkötött mezőgazdasági biztosítás díjához 65 százalékos támogatásban részesülhetnek a termelők. A rendelkezésre álló forrásokat meghaladó támogatási igény esetén azonban visszaosztás (a támogatási intenzitás csökkentése) alkalmazandó, a támogatási intenzitás csökkentése az egyes biztosítási típusoknál eltérően történik.

\section{A díjtámogatás visszaosztása}

A visszaosztás számítása a „C” típusú biztosítások támogatásintenzitásának csökkentésével kezdődik, majd ezt követi a „B” típusú biztosítások díjtámogatásának visszaosztása, és az „A” típusú biztosítások támogatása csak legvégül kerül csökkentésre. Az „A” típusú biztosítás ugyanis elsőbbséget élvez, mivel ez a csomagbiztosítás több kockázat ellen véd, és ezért ezt célszerü kiemelten támogatni. Amennyiben a forrás még így sem elegendő a dijtámogatásra, mindhárom biztosítási típus díjának támogatása arányosan csökkentésre kerül.

A díjtámogatási rendszer kezdetektől fogva így került kialakításra, hiszen a visszaosztás alkalmazásával biztosítható, hogy valamennyi jogosult termelő támogatáshoz jusson, ugyanakkor az intézkedés forrása is tervezhető. A korábbi évekhez képest lényeges változást jelent azonban, hogy 2016-tól a díjtámogatásnak van garantált minimális szintje. A „B” és „C” típusú biztosítások esetében ez az alsó limit 30, az „A” típusú biztosításoknál pedig 41,25 százalék. Kismértékben módosult a visszaosztás számításának menete is, ezzel a „C” típusú biztosítások támogatásintenzitása kedvezőbbé vált. A támogatásintenzitás csökkentésének sorrendjét és a bekövetkezett változásokat a 3. táblázat szemlélteti.
3. táblázat: A támogatásintenzitás alakulása az egyes konstrukciók esetében

\begin{tabular}{|c|c|c|}
\hline $\begin{array}{l}\text { A támogatásintenzitás csökkentésének } \\
\text { sorrendje }\end{array}$ & 2012-2015 & 2016-tól (VP) \\
\hline 1. „C" típusú biztosítások esetében & $30 \%$-ig & $40 \%$-ig \\
\hline 2. „B” típusú biztosítások esetében & $40 \%$-ig & $40 \%$-ig \\
\hline 3. „A" típusú biztositások esetében & $55 \%$-ig & $55 \%$-ig \\
\hline 4. mindhárom típus esetén arányosan & nines alsó korlát & $\begin{array}{l}\text { „A" típus esetén } 41,25 \% \text {-ig, } \\
\text { „B" és „C" típus esetén } 30 \% \text {-ig }\end{array}$ \\
\hline
\end{tabular}

Forrás: saját szerkesztés

Lényeges változás tehát, hogy a „C” típusú biztosítások támogatási intenzitása első körben nem 30, hanem csak 40 százalékig csökken. Ezt az indokolta, hogy a szántóföldi növények biztosítása gyakran integrátoron keresztül történik, mintegy 20 százalékkal alacsonyabb díjjal, és a termelők számára - a dijjtámogatott biztosítások adminisztrációját is figyelembe véve már nem volt elég vonzó a 30 százalékos dítámogatás. A módosítás következtében - mivel az a legnagyobb vetésterülettel rendelkező növényeket érintette - a termelök szélesebb köre juthat a korábbiakhoz képest magasabb mértékű díjtámogatáshoz.

2016-ban közel 11200 termelő kötött díjtámogatott biztosítást (2015-ben még csak 8 605), így a támogatási igény ismét meghaladja a rendelkezésre álló forrásokat, ezért a 2014es és 2015-ös évhez hasonlóan a 2016. évi biztosítási dijtámogatás esetén is visszaosztás vált szükségessé. A kifizető ügynökségtől származó információk alapján az „A” típusú biztosítást kötő termelők a biztosítási díj 65, a „B” típusú biztosítással rendelkező termelők a díj 43, míg a „C" típusú biztosítást kötő termelők a befizetett biztosítási díj 40 százalékát kaphatták vissza támogatásként.

Az elmúlt öt év támogatási intenzitását a 4. táblázat szemlélteti.

4. táblázat: A támogatások intenzitása módozatonként 2012-2016

\begin{tabular}{|l|c|c|c|}
\hline Év & „A" típusú biztosítás & „B” típusú biztositás & „C" típusú biztosítás \\
\hline 2012 & $65 \%$ & $65 \%$ & $65 \%$ \\
\hline 2103 & $65 \%$ & $65 \%$ & $65 \%$ \\
\hline 2014 & $65 \%$ & $63 \%$ & $30 \%$ \\
\hline 2015 & $65 \%$ & $52 \%$ & $30 \%$ \\
\hline 2016 & $65 \%$ & $43 \%$ & $40 \%$ \\
\hline
\end{tabular}

Forrás: $M V H$ 


\section{A biztosítási díjtámogatás igénylése}

2016-tól a mezőgazdasági biztosítási díjtámogatás a Vidékfejlesztési Program (VP) keretében került meghirdetésre, aminek következtében kismértékben módosultak a támogatási feltételek, melyeket a korábbi jogszabály (19/2014. FM rendelet) helyett a Pályázati Felhívás, illetve a VP Irányító Hatóságának közleményei szabályoznak. Az új rendszer kialakításakor az a cél vezérelte a döntéshozókat, hogy a lehető legkevesebb változtatással kerüljön át a biztosítási díjtámogatás a VP intézkedései közé, és a már megszokott eljárások, támogatási feltételek megmaradjanak.

Ennek köszönhetően a 2015-ös átmeneti év után ismét támogatási jogosultságot szerezhetnek a mezőgazdasági nagyvállalkozások, valamint újra az Egységes Kérelem felületen kell igényelni a biztosítási dijtámogatást (a 2012-2014-ig terjedő időszak gyakorlatával megegyezően).

Az EK-n beadott támogatási kérelem egyúttal kifizetési igénylésnek is minősül. A támogatási kérelmek benyújtására a tárgyévi egységes kérelemről szóló rendeletben meghatározott, az Egységes kérelem benyújtására nyitva álló időszakban van lehetőség.

A biztosítási díjtámogatási igény EK-n történő jelölésén kívül a termelőknek a támogatás igényléséhez mindössze annyit kell tenniük, hogy megkötik a jogosultsági feltételeknek megfelelő biztosítási szerződést, és megfizetik a biztosítási díjat. Támogatás ugyanis csak a ténylegesen megfizetett biztosítási díj után fizethető.

A jogosultsági feltételek ellenőrzéséhez szükséges adatokat (szerződés adatai, díj igazolása) a biztosító küldi meg a kifizető ügynökség részére. Az ellenőrzéseket követően a VP Irányító Hatósága a mezőgazdasági biztosítás díjához nyúitott támogatásról Támogatói Okiratot állít ki, amely tartalmazza a támogatás összegét, valamint a támogatás intenzitását.

A VP-ben a 17.1.1 számú a „Mezőgazdasági biztosítások díjához nyújtott támogatás” című intézkedés keretösszege 2020-ig 29,56 milliárd forintban került megállapításra. Ez a keretösszeg lehetővé tette, hogy a biztosítási díjtámogatás éves forrása 2016-ban 4 milliárd forintra emelkedjen az előző évi 3 milliárd forinthoz képest. 2017-ben ugyanezzel a 4 milliárd forintos keretösszeggel került meghirdetésre a mezőgazdasági biztosítási díjtámogatás, amely a mezőgazdasági termelők számára megnyugtató módon garantálja a rendszer működését, és ösztönzi a termelői öngondoskodást.

A támogatási program elmúlt 5 éve során fokozatosan bővült a biztosítható kockázatok száma, illetve módosult a biztosítható növények köre. 2017-ben ez tovább folytatódott. A káresemények definícióját meghatározó Mkk. törvény (2011. évi CLXVIII. tv.) módosulása miatt ugyanis a tavaszi fagy kockázata valamennyi növényre kiterjesztésre került, valamint bővült az aszálydefiníció. Eddig az aszálydefiníció kizárólag a lehullott csapadékmennyiségen alapult, ami kiegészítésre került a napi maximum hőmérsékleti adatokkal. A módosítást követően aszálynak az a jelenség minősül, ha 30 egymást követö napon belül a csapadék összes mennyisége a $10 \mathrm{~mm}$-t nem éri el, vagy 30 egymást követö napon a csapadék összes mennyisége a $25 \mathrm{~mm}$-t nem éri el, és a napi maximum hömérséklet legalább 15 napon meghaladja a 31 C fokot. A fenti két kritérium egyikének teljesülése is elegendő az aszály megállapításához.

A törvényi definíciómódosulások vonatkoznak a biztosítási díjtámogatási rendszerre is, ezért a díjtámogatott mezőgazdasági biztosítások nyújtotta védelem bővül. Ez remélhetően hozzájárul a termelők biztosításkötési hajlandóságának javulásához, az ügyfél-elégedettség növeléséhez, és tovább bővül azon termelők köre, akik a mezőgazdasági kockázatkezelésnek ezt a formáját, azaz a biztosításkötést választják.

\section{IRODALOMJEGYZÉK}

2011. évi CLXVIII. törvény a mezőgazdasági termelést érintỏ időjááási és más természeti kockázatok kezeléséró 143/2011.(XII.23.) FM rendelet a mezogazdasági biztositás dijąhoz nyujitott támogatás igénybevételi feltételeiró

Azzurópai Parlament és a Tanács 1305/2013/EU rendelete az Európai Mezőgazdasági Vidékfejlesztési Alapból (EMVA) nyujtando vidékfejlesztési támogatásrô

Felhívás a mezögazdasági biztositás dijához nyúitott támogatásról (VP3-17.1.1-16) 